\title{
Halobacterium sodomense sp. nov., a Dead Sea Halobacterium with an Extremely High Magnesium Requirement
}

\author{
AHARON OREN \\ Department of Microbiology, University of Illinois, Urbana, Illinois 61801
}

\begin{abstract}
A strain of Halobacterium was isolated from the Dead Sea. This isolate differs from the previously isolated halobacteria in (i) its requirement for sodium ions, which is lower than that of most other halobacteria $(\geq 0.5 \mathrm{M})$, (ii) its requirement for divalent cations $\left(\mathrm{Mg}^{2+}\right.$ or $\left.\mathrm{Ca}^{2+}\right)$, which is higher than that of most other halobacteria (optimal growth was obtained in the presence of 0.6 to $1.2 \mathrm{M} \mathrm{Mg}^{2+}$ ), (iii) its requirement for either starch or clay minerals (bentonite) for growth in the standard growth medium used, and (iv) its synthesis of purple membrane at low oxygen tensions in the light. This organism has been designated Halobacterium sodomense sp. nov. The type strain is strain ATCC 33755.
\end{abstract}

The genus Halobacterium includes red-colored, rod-shaped bacteria that require $\mathrm{NaCl}$ concentrations of $3 \mathrm{M}$ or more for growth (8) and possess special biochemical characteristics, including cellular lipids with ether bonds, absence of peptidoglycan, glycoproteins in the cell wall, and characteristic base sequences in the ribosomal ribonucleic acid. These properties place the halobacteria in the archaebacteria (18). Halobacteria are found in many hypersaline bodies of water, such as salterns, the Great Salt Lake in Utah, and the Dead Sea.

Since the pioneering work of Volcani more than 40 years ago (29), it has been known that the Dead Sea is inhabited by red halobacteria, colorless bacteria, and unicellular algae. Phasecontrast microscopy of Dead Sea water samples has shown that the dominant bacteria are cup- or disk-shaped pleomorphic organisms. A minor part of the population consists of long, rodshaped bacteria $(16,22)$. The pleomorphic cupshaped, red halobacteria include Halobacterium volcanii, which was isolated by Mullakhanbhai and Larsen (21), a strain resembling the lost isolate of "Halobacterium marismortui" of Volcani $(29,30)$, which was isolated by Ginzburg et al. (10), and additional strains isolated by me (22). All of these strains have a relatively low requirement for sodium ions and a high magnesium tolerance, making them well adapted for life in the Dead Sea. Isolation of long, rodshaped bacteria has not been reported.

I succeeded in isolating a rod-shaped, red halobacterium from the Dead Sea by using media containing starch. This organism appears to be distinct from previously described species.

\section{MATERIALS AND METHODS}

Source of organism. Strain RD-26 ${ }^{\mathrm{T}}$ (type strain) was isolated from a surface water sample collected in May
1980 from the Dead Sea, about $8 \mathrm{~km}$ east of Ein Gedi (station 5 [1]). This strain was used in all experiments.

Isolation and culture methods. I used the observation of Kritzman (G. Kritzman, M.Sc. thesis, The Hebrew University of Jerusalem, Jerusalem, Israel, 1973; G. Kritzman, P. Keller, and Y. Henis, Abstr. 1st Int. Cong. Bacteriol., vol 2, p. 242, 1973) that the inclusion of starch in the medium permitted efficient enumeration of Dead Sea halobacteria. Organisms were isolated in medium containing $1 \mathrm{~g}$ of peptone (Difco Laboratories), $1 \mathrm{~g}$ of yeast extract (Difco), $20 \mathrm{~g}$ of potato starch (Baker and Adamson), $800 \mathrm{ml}$ of Dead Sea water, and $200 \mathrm{ml}$ of distilled water $(\mathrm{pH} 6.5$ to 7.0 ). The isolation plates consisted of two layers; the lower layer contained 2\% (wt/vol) agar (Difco), and the upper layer contained $0.5 \mathrm{ml}$ of a water sample or a dilution of a sample in autoclaved Dead Sea water mixed with $4.5 \mathrm{ml}$ of molten isolation medium containing $0.8 \%$ agar. After solidification of the upper layer, the plates were incubated at $37^{\circ} \mathrm{C}$. Colonies were visible after 2 to 3 weeks. Pure cultures were obtained by repeated streaking onto a $2 \%$ agar medium of the same composition. The plates were incubated for 2 to 3 weeks before the colonies reached a convenient size for transfer.

Pure cultures were grown in a medium containing $125 \mathrm{~g}$ of $\mathrm{NaCl}, 160 \mathrm{~g}$ of $\mathrm{MgCl}_{2} \cdot 6 \mathrm{H}_{2} \mathrm{O}, 0.13 \mathrm{~g}$ of $\mathrm{CaCl}_{2} \cdot 2 \mathrm{H}_{2} \mathrm{O}, 5.0 \mathrm{~g}$ of $\mathrm{K}_{2} \mathrm{SO}_{4}, 1 \mathrm{~g}$ of peptone (Difco), 1 $\mathrm{g}$ of yeast extract (Difco), $2 \mathrm{~g}$ of soluble starch (BDH), and distilled water to a final volume of 1 liter; the $\mathrm{pH}$ of this medium was adjusted to 7.0 with $\mathrm{NaOH}$ before autoclaving. Cells were grown in 100-ml Erlenmeyer flasks containing $50 \mathrm{ml}$ of medium or $50-\mathrm{ml}$ flasks containing $25 \mathrm{ml}$ of medium in a shaking water bath at $35^{\circ} \mathrm{C}$. For experiments to determine purple membrane formation, $150-\mathrm{ml}$ portions were grown in $250-\mathrm{ml} \mathrm{Er}$ lenmeyer flasks in an orbital shaker (Psycrotherm; New Brunswick Scientific Co.) illuminated by white fluorescent light at an intensity of $3 \times 10^{3} \mathrm{ergs} / \mathrm{cm}^{2}$ per s. To determine growth requirements, the concentrations of $\mathrm{NaCl}, \mathrm{MgCl}_{2} \cdot 6 \mathrm{H}_{2} \mathrm{O}, \mathrm{CaCl}_{2} \cdot 2 \mathrm{H}_{2} \mathrm{O}$, starch, bentonite (Evans), and kaolin (Merck) in the growth medium were modified. Growth was measured by determining the optical densities of the cultures at 600 

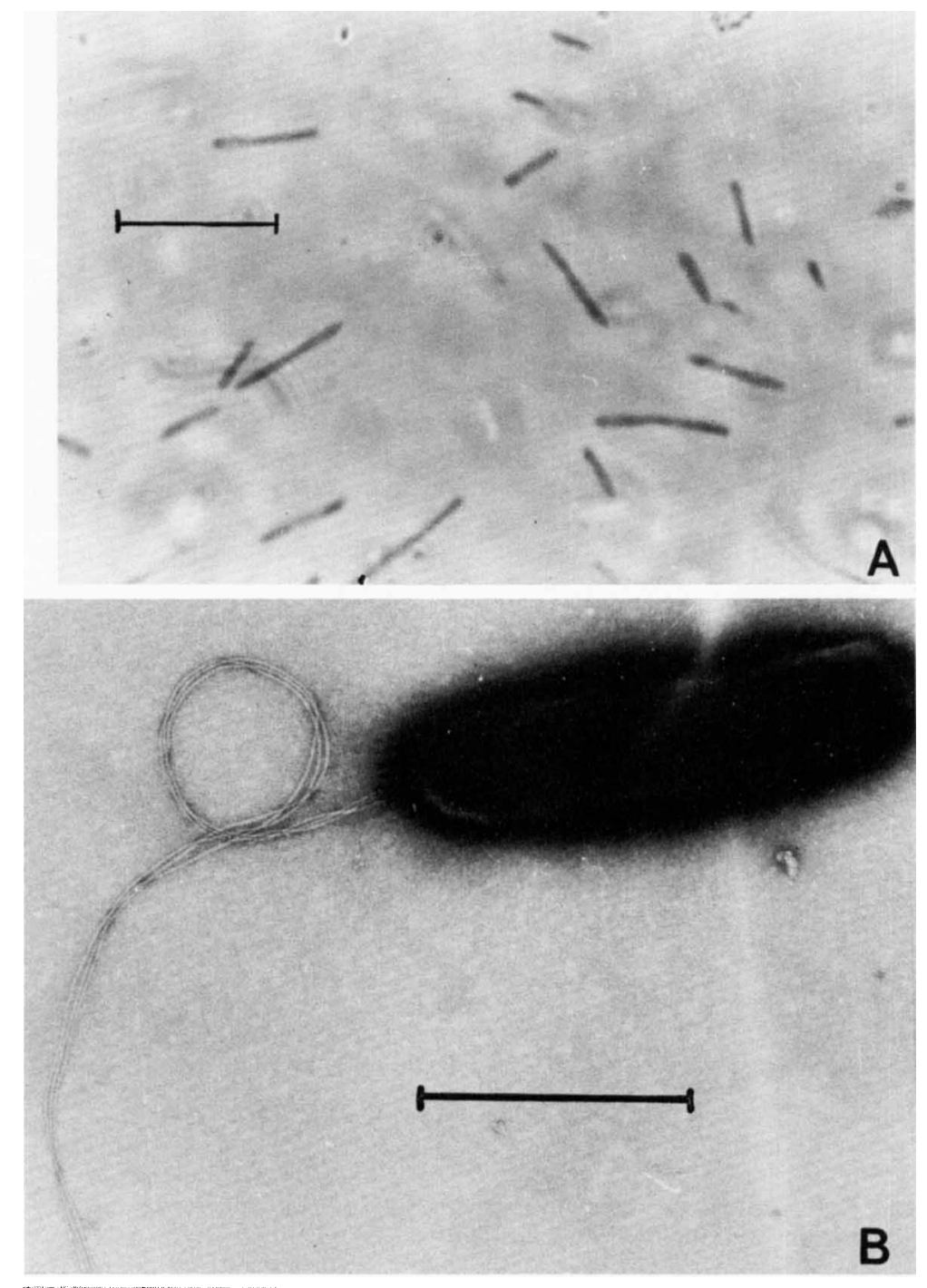

FIG. 1. (A) Halobacterium strain RD-26 $6^{T}$ cells grown in standard liquid medium. Phase-contrast microscopy. Bar $=10 \mu \mathrm{m}$. (B) Electron micrograph of a cell grown in standard liquid growth medium. Negatively stained preparation. Bar $=1 \mu \mathrm{m}$.

$\mathrm{nm}$ with a model $300-\mathrm{N}$ spectrophotometer (Gilford Instrument Laboratories, Inc.), using uninoculated growth medium as a blank. Pure cultures were maintained on slants of growth medium supplemented with $1.5 \%$ agar.

Electron microscopy. Bacteria were negatively stained with $1 \%$ aqueous uranyl acetate by washing 1 drop of bacterial suspension with stain. Micrographs were obtained with a Philips model EM-400 electron microscope operated at $80 \mathrm{kV}$.

Carotenoid extraction. Carotenoids were extracted in methanol-acetone $(1: 1, \mathrm{vol} / \mathrm{vol})(11)$, and the absorption spectra of these compounds were determined with a model 402 spectrophotometer (Perkin-Elmer Corp.), using the solvent as a blank.

Purple membrane. The purple membrane assay was performed as described previously (23).
Biochemical tests. Gram staining was performed after smears were fixed on slides with acetic acid by the method of Dussault (5). The cellular lipids were partially characterized by the method of Ross et al. (24) and were compared with the cellular lipids of Escherichia coli, $H$. volcanii (21), and the Halobacterium of the Dead Sea described by Ginzburg $(7,9)$.

Acid production from carbohydrates was determined by measuring the $\mathrm{pH}$ in starch-free growth medium containing bentonite $(0.02 \%)$ and filter-sterilized carbohydrates at final concentrations of $1.0 \%$.

The susceptibility of the organism to antibiotics and vibriostatic agent $0 / 129$ was tested in growth medium for 4 to 5 days after inoculation. The inhibitors tested were penicillin $\mathrm{G}(25 \mathrm{U} / \mathrm{ml})$, kanamycin $(30 \mu \mathrm{g} / \mathrm{ml})$, novobiocin $(10 \mu \mathrm{g} / \mathrm{ml})$, chloramphenicol succinate $(30$ $\mu \mathrm{g} / \mathrm{ml})$, streptomycin sulfate $(30 \mu \mathrm{g} / \mathrm{ml})$, bacitracin $(5$ 


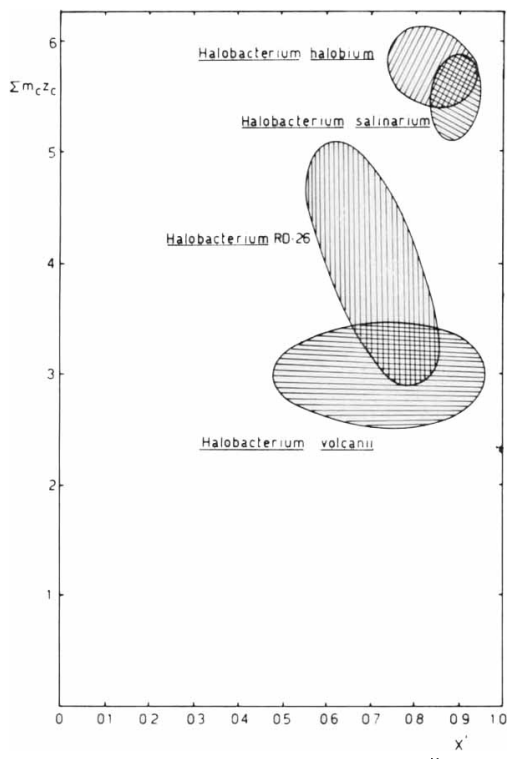

FIG. 2. Growth of Halobacterium strain RD-26 ${ }^{\mathrm{T}}$ compared with growth of $H$. volcanii, $H$. halobium, and $H$. salinarium, plotted onto the environmental space by the method of Edgerton and Brimblecombe (6). The $x$-axis $\left(X^{\prime}\right)$ represents the mole fraction of monovalent cations $\left(\mathrm{mNa}^{+}+\mathrm{mK}^{+}\right) /\left(\mathrm{mNa}^{+}+\mathrm{mK}^{+}+\right.$ $\left.\mathrm{mMg}^{2+}+\mathrm{mCa}^{2+}\right)$, and the $\mathrm{y}$-axis represents the total charge concentration $\left(\mathrm{mNa}^{2+}+\mathrm{mK}^{+}+2 \mathrm{mMg}^{2+}\right)(\mathrm{m}$, molal concentration). The values for the optimal growth conditions for $H$. volcanii, $H$. halobium, and $H$. salinarium were taken from Edgerton and Brimblecombe (6).

and $20 \mathrm{U} / \mathrm{ml}$ ), and vibriostatic agent 0/129 (2,4-diamino-6,7-diisopropylpteridine phosphate; BDH) (10 and $50 \mu \mathrm{g} / \mathrm{ml}$ ). In addition, I tested susceptibility to penicillin, chloramphenicol, erythromycin, kanamycin, neomycin, and tetracycline by the agar disk method.

Oxidase was detected by the method of Gonzalez et al. (12). Catalase, reduction of nitrate (in growth medium supplemented with $1 \% \mathrm{NaNO}_{3}$ ), and indole production (in growth medium or in growth medium enriched with $0.1 \%$ tryptophan or with $0.5 \%$ yeast extract) were tested by the procedures of Holding and Collee (13). Starch hydrolysis was tested by flooding growth on plates containing $0.2 \%$ starch agar with aqueous iodine solution.

DNA preparation and characterization. Deoxyribonucleic acid (DNA) was extracted and purified by the method of Marmur (20), and its guanine-plus-cytosine $(\mathrm{G}+\mathrm{C})$ content was determined by equilibrium density gradient centrifugation in $\mathrm{CsCl}(19)$; calf thymus DNA (Sigma Chemical Co.) ( $39 \mathrm{~mol} \% \mathrm{G}+\mathrm{C}$ ) was used as the standard. Plasmids were isolated by polyacrylamide gel electrophoresis (2).

\section{RESULTS}

Strain RD-26 ${ }^{\mathrm{T}}$ was a gram-negative, slender, rod-shaped bacterium ( 0.5 by 2.5 to $5 \mu \mathrm{m})$ when it was grown in standard growth medium (Fig. 1a). When this organism was grown at suboptimal magnesium concentrations (see below), the cells were shorter, and in extreme cases pleomorphic rods and spheres were observed. The cells were motile by means of a tuft of polar flagella (Fig. 1b), like Halobacterium halobium (14). Gas vacuoles, which are sometimes found in halobacteria, particularly in fresh isolates $(14$, 25 ), were never observed in any of the strains isolated. Upon gradual dilution of a liquid culture with water, the cells were transformed to spherical structures, which lysed when the culture was diluted further.

At $35^{\circ} \mathrm{C}$ optimum growth occurred at an $\mathrm{NaCl}$ concentration of about $2 \mathrm{M}$ (in the presence of 0.6 to $1.2 \mathrm{M} \mathrm{MgCl}_{2}$ ); minimal doubling times were $12 \mathrm{~h}$. At an $\mathrm{NaCl}$ concentration of $4.3 \mathrm{M}$ growth rates were relatively low. The specific requirement for sodium was exceptionally low, and fair growth was obtained at sodium concentrations as low as $0.5 \mathrm{M}$. Increased magnesium concentrations were then required to provide the necessary osmotic pressure in the medium. Magnesium concentrations as high as 0.6 to 1.2 $M$ were required for optimal growth; lower concentrations caused lowered growth rates and a change in cell morphology to pleomorphic rods and spheres. Higher sodium concentrations did not depress the requirement for magnesium. Calcium at least partly replaced magnesium, and high growth rates and rod-shaped cells were obtained in medium containing $1 \mathrm{M} \mathrm{CaCl}_{2}, 15$ $\mathrm{mM} \mathrm{MgCl}$, and $2.1 \mathrm{M} \mathrm{NaCl}$. Figure 2 compares the growth requirements of Halobacterium strain RD-26 ${ }^{\mathrm{T}}$ with respect to mono- and divalent cations with the growth requirements of the Dead Sea isolate $H$. volcanii (21) and with the growth requirements of $H$. halobium and Halobacterium salinarium. The salt concentrations that allowed growth are plotted in this figure in the "environmental space" of the different combinations of mono- and divalent cations possible, according to the method of Edgerton and Brimblecombe (6). In this plot the $\mathrm{x}$-axis represents the mole fraction of monovalent cations, and the y-axis represents the total ionic strength of the medium. Figure 2 shows that Halobacterium strain RD-26 ${ }^{T}$ resembled $H$. volcanii in its salt requirements for optimal growth, although the former showed optimal growth at a somewhat higher total ionic strength and somewhat lower ratios of monovalent cations to divalent cations; both strains differed greatly from $H$. halobium and $H$. salinarium in the lower ionic strength and the higher divalent cation concentrations required for growth. The optimal growth temperature of strain RD- $26^{\mathrm{T}}$ was $40^{\circ} \mathrm{C}$ in standard growth medium; no growth was obtained below $20^{\circ} \mathrm{C}$ or above $50^{\circ} \mathrm{C}$. When starch was 


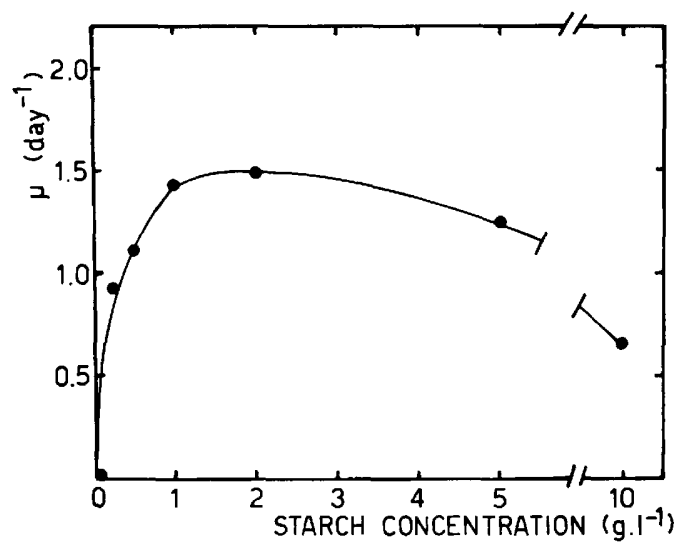

FIG. 3. Effect of starch concentration on the growth of Halobacterium strain RD-26 ${ }^{\mathrm{T}}$. Cells were grown in 100-ml Erlenmeyer flasks containing $50-\mathrm{ml}$ portions of standard growth medium in which the starch concentration was varied. $\mu$, Growth rate.

omitted from the standard growth medium, no growth occurred. A starch concentration of $0.2 \%$ was optimal for growth (Fig. 3). However, starch-free medium did support growth when clay minerals like bentonite or kaolin $(0.05 \%)$ were added, although the final growth yields were only $40 \%$ of those in the presence of starch.

Cells were rich in carotenoids. Extracts of cells in methanol-acetone $(1: 1)$ showed absorption maxima at $371,388,471,498$, and $532 \mathrm{~nm}$ (Fig. 4); these were similar to the absorption maxima reported for extracts of other Halobacterium strains. After prolonged incubation in the light, the cultures assumed a purple color due to the formation of purple membrane (23). Purple membrane formation was stimulated markedly by reducing the oxygen tension and was light dependent.

Characterization of the lipids of Halobacterium strain $\mathrm{RD}-26^{\mathrm{T}}$ by thin-layer chromatography (24) showed the presence of ether-linked lipids similar to those of the archaebacteria (18), H. volcanii, and the Halobacterium of the Dead Sea of Ginzburg and distinctly different from the ester-linked lipids of $E$. coli.

The $\mathrm{G}+\mathrm{C}$ content of the DNA of strain RD$26^{\mathrm{T}}$ was $68 \mathrm{~mol} \%$, as determined by buoyant density. No satellite DNA was detected. A single plasmid was found (R. D. Simon and A. Oren, unpublished data).

In starch-free growth medium supplemented with $0.05 \%$ bentonite, cultures produced acid from D-glucose, D-fructose, sucrose, D-xylose, $\mathrm{D}$-maltose, and glycerol; the final $\mathrm{pH}$ was 3.9 to 4.9 after 5 days. Little or no acid was produced from D-ribose, D-galactose, lactose, L-arabinose, dulcitol, D-mannitol, or L-rhamnose.
Strain RD-26 ${ }^{\mathrm{T}}$ was catalase positive and oxidase positive and slowly reduced nitrate to nitrite. No indole was produced from tryptophan. Of the various antibiotics tested, only bacitracin and novobiocin inhibited growth, as in other members of the genus Halobacterium; strain RD-26 ${ }^{\mathrm{T}}$ was also susceptible to vibriostatic agent 0/129. Penicillin, kanamycin, chloramphenicol, neomycin, tetracycline, erythromycin, and streptomycin did not inhibit growth at the concentrations used.

\section{DISCUSSION}

The genus Halobacterium includes strains displaying a wide range of relationships toward magnesium and other divalent cations. Certain types of halobacteria, those which thrive in alkaline soda lakes, proliferate in the absence of magnesium, and to them even low concentrations of magnesium and other divalent cations are toxic $(15,26)$. The pleomorphic cup-shaped Dead Sea species $H$. volcanii not only requires high magnesium concentrations $(0.1 \mathrm{M})(21)$, but also shows tolerance toward extremely high magnesium concentrations and is able to grow at one-half its maximal growth rate in $1.4 \mathrm{M} \mathrm{Mg}^{2+}$ (21). The commonly studied species $H$. salinarium and $H$. halobium are intermediate between these extremes (3). Strain RD-26 displayed the highest requirement for divalent cations of all of the organisms described to date; optimal growth occurred in 0.6 to $1.2 \mathrm{M} \mathrm{Mg}^{2+}$ (in the presence of $2.1 \mathrm{M} \mathrm{NaCl}$ ). Increasing the sodium concentration depressed the magnesium requirement of this organism very little.

In addition, Halobacterium strain RD- $26^{\mathrm{T}}$ differed from the previously described halobacteria in its relatively low requirement for $\mathrm{NaCl}$; the

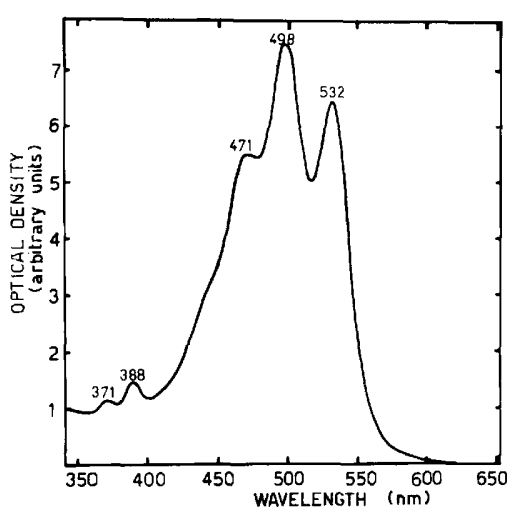

FIG. 4. Absorption spectrum of a methanol-acetone extract of Halobacterium strain RD-26 ${ }^{\mathrm{T}}$. Cells grown in standard medium were extracted with methanolacetone $(1: 1)(11)$, and the absorption spectrum of the extract was determined. 
optimal $\mathrm{NaCl}$ concentration observed for this strain $(1.7$ to $2.5 \mathrm{M})$ is markedly lower than the concentration generally reported for the other halobacteria (4.2 M) (8). In fact, the optimal $\mathrm{NaCl}$ concentration for strain $\mathrm{RD}-26^{\mathrm{T}}$ is close to the minimal values $(2.0$ to $3.0 \mathrm{M})$ reported for most other halobacteria (8). A similar low sodium requirement has been found in the pleomorphic Dead Sea species $H$. volcanii, and this value closely resembles the relatively low sodium concentration of Dead Sea water (1977 average value, $1.74 \mathrm{M})(1)$; in addition, its extremely high magnesium tolerance makes strain RD- $26^{\mathrm{T}}$ well fitted for life in the Dead Sea, which has very high magnesium concentrations (1977 average value, $1.81 \mathrm{M}$ ) (1). The specific requirement for sodium was very low; Halobacterium strain RD-26 ${ }^{\mathrm{T}}$ grew relatively well in $0.5 \mathrm{M} \mathrm{NaCl}$ (in the presence of 1.5 to $2.0 \mathrm{M} \mathrm{MgCl}_{2}$ ), distinguishing this strain from the other halobacteria that have been described. This finding makes it necessary to extend the definition of the genus Halobacterium with respect to the salt requirement.

Halobacterium strain RD- $26^{\mathrm{T}}$ fermented a variety of sugars to acid products, a property shared by other Dead Sea isolates, such as the Halobacterium of the Dead Sea of Ginzburg (30) and $H$. volcanii (Oren, unpublished data), and additional strains isolated from other habitats, such as Halobacterium saccharovorum $(25,26)$ and Halobacterium vallismortis (12); the more extensively studied species $H$. halobium and $H$. salinarium lack this property (4).

When starch was omitted from the growth medium, no growth occurred. The dependence of many Dead Sea bacteria on the presence of starch in the medium for growth has been observed previously, even though some of these organisms do not utilize starch (Kritzman, M.Sc. thesis). Among the many carbohydrates and other substances which I tested (including glucose, cellulose, gelatin, dextran, and levan), only starch and the structurally related compound glycogen promoted growth of Halobacterium strain RD-26 ${ }^{\mathrm{T}}$. However, starch could be replaced by clay minerals, such as bentonite or kaolin. Perhaps the clay minerals and starch promote growth of strain RD- $26^{\mathrm{T}}$ by acting as scavengers of toxic metabolities excreted by the bacterium or by adsorbing toxic components from the medium.

Strain RD-26 ${ }^{\mathrm{T}}$ is probably similar to the rodshaped bacteria observed by Kaplan and Friedman (16) in the Dead Sea $(0.5 \%$ of the bacterial population in surface waters; almost $100 \%$ of the population at a depth of $250 \mathrm{~m}$ ) and grown by them in enrichment cultures. Kritzman, (M.Sc. thesis) grew colonies of red bacteria on plates containing starch, but he did not characterize these bacteria further, and no cultures were preserved. The high purple membrane content of the bacterial community of the Dead Sea analyzed during a dense bloom of bacteria at the beginning of 1981 (23) strongly suggests the presence of large numbers of an organism like strain RD-26 ${ }^{\mathrm{T}}$ in the lake, as the pleomorphic cup-shaped halobacteria from the Dead Sea have never been shown to produce bacteriorhodopsin $(7,9$; H. Larsen, personal communication). Strain RD- $26^{\mathrm{T}}$ is one of the few Halobacterium strains described that produce purple membrane. The only other halobacteria which have been reported to do this are $H$. halobium and Halobacterium cutirubrum, which have recently been placed in a separate species (4).

The $\mathrm{G}+\mathrm{C}$ content of strain RD-26 ${ }^{\mathrm{T}}$ DNA was $68 \mathrm{~mol} \%$, which is well within the range of values commonly reported for the halobacteria (8). Other halobacteria reportedly contain an additional DNA fraction (10 to $30 \%$ of the total DNA) with a lower $\mathrm{G}+\mathrm{C}$ content (57 to 60 mol\%). This satellite DNA probably consists of plasmids (25). In my equilibrium density gradient centrifugation patterns no satellite DNA band was visible. However, the presence of a single plasmid was demonstrated. The fact that no additional DNA band was found in the $\mathrm{CsCl}$ gradient may be due to one or both of the following reasons: the quantities of the plasmid are too small, or the $\mathrm{G}+\mathrm{C}$ content of the plasmid is too close to that of the major DNA fraction to be resolved as a separate band.

My data suggest that sirain RD-26 ${ }^{\mathrm{T}}$ is sufficiently different from the currently recognized species in the genus Halobacterium to warrant designation as a new species, and I propose the name Halobacterium sodomense (so.do.men'se. N. L. adj. sodomense pertaining to Sodom, near the Dead Sea, from which the organism was isolated) for this species. Strain RD-26 ${ }^{\mathrm{T}}$ has been deposited in the American Type Culture Collection as strain ATCC $33755^{\mathrm{T}}$.

The following description is given in compliance with the rules and recommendations of the International Code of Nomenclature of Bacteria (17).

Halobacterium sodomense sp. nov. Rods that are 0.5 by $2.5 \mu \mathrm{m}$ and motile by a tuft of polar flagella. Gram-negative. Gas vacuoles lacking. Colonies small, round, convex, entire, translucent, and reddish orange.

Chemoorganotrophic; aerobic. Yeast extract and peptone are good sources of organic nutrients. No growth occurs anaerobically with nitrate. The presence of starch or clay minerals (bentonite, kaolin) in the medium is essential for growth.

Requires at least $0.5 \mathrm{M} \mathrm{NaCl}$ for growth. Optimal $\mathrm{NaCl}$ concentration range, 1.7 to $2.5 \mathrm{M}$ 
at $35^{\circ} \mathrm{C}$; optimal $\mathrm{MgCl}_{2}$ concentration, 0.6 to 1.2 $\mathrm{M}$ (in the presence of $2 \mathrm{M} \mathrm{NaCl}$ ). Fair growth occurs at $1.8 \mathrm{M} \mathrm{MgCl}_{2}$ and $1.7 \mathrm{M} \mathrm{NaCl}$ and at 2.5 $\mathrm{M} \mathrm{MgCl}_{2}$ and $0.5 \mathrm{M} \mathrm{NaCl}$. Optimum temperature, $40^{\circ} \mathrm{C}$ (in medium containing $2.1 \mathrm{M} \mathrm{NaCl}$ and $0.78 \mathrm{M} \mathrm{MgCl}_{2}$ ).

Pigmented red due to carotenoids. Bacteriorhodopsin produced in the light under reduced oxygen tensions.

Nitrate slowly reduced to nitrite.

No indole produced from tryptophan.

Susceptible to novobiocin, bacitracin, and vibriostatic agent 0/129.

Acid produced from glucose, fructose, sucrose, xylose, maltose, and glycerol; little or no acid produced from galactose, mannose, lactose, arabinose, rhamnose, ribose, or mannitol.

Starch hydrolyzed.

Oxidase and catalase positive.

Isolated from the Dead Sea.

$\mathrm{G}+\mathrm{C}$ content of the type strain, $68 \mathrm{~mol} \%$ (as determined by buoyant density).

Type strain: ATCC 33755 (= RD-26).

\section{ACKNOWLEDGMENTS}

I thank M. Kessel (The Hebrew University of Jerusalem) for providing the electron micrograph, R. D. Simon (University of Rochester) for the plasmid isolation, and M. Shilo (The Hebrew University of Jerusalem) for stimulating discussions.

This work was supported by a grant from the Israeli Ministry of Energy and Infrastructure.

\section{LITERATURE CITED}

1. Beyth, M. 1980. Recent evolution and present stage of Dead Sea brines, p. 155-165. In A. Nissenbaum (ed.), Hypersaline brines and evaporitic environments. Elsevier, Amsterdam.

2. Birnboim, H. C., and J. Doly. 1979. A rapid alkaline extraction procedure for screening recombinant plasmid DNA. Nucleic Acids Res. 7:1513-1523.

3. Brown, H. J., and N. E. Gibbons. 1955. The effect of magnesium, potassium, and iron on the growth and morphology of red halophilic bacteria. Can. J. Microbiol. 1:486-494

4. Colwell, R. R., C. D. Litchfield, R. H. Vreeland, L. A. Kiefer, and N. E. Gibbons. 1979. Taxonomic studies of red halophilic bacteria. Int. J. Syst. Bacteriol. 29:379-399.

5. Dussault, H. P. 1955. An improved technique for staining red halophilic bacteria. J. Bacteriol. 70:484-485.

6. Edgerton, M. E., and P. Brimblecombe. 1981. Thermodynamics of halobacterial environments. Can. J. Microbiol. 27:899-909.

7. Evans, R. W., S. C. Kushwaha, and M. Kates. 1980. The lipids of Halobacterium marismortui, an extremely halophilic bacterium of the Dead Sea. Biochim. Biophys. Acta 619:533-544.

8. Gibbons, N. E. 1974. Halobacteriaceae, p. 269-273. In R. E. (Buchanan and N. E. Gibbons (ed.), Bergey's manual of determinative bacteriology, 8 th ed. The Williams \& Wilkins Co., Baltimore.

9. Ginzburg, M. 1978. Ion metabolism in whole cells of Halobacterium halobium and $H$. marismortui, p. 561-577. In S. R. Caplan and M. Ginzburg (ed.), Energetics and structure of halophilic microorganisms. Elsevier, Amsterdam.

10. Ginzburg, M., L. Sachs, and B. Z. Ginzburg. 1970. Ion metabolism in a Halobacterium. I. Influence of age of culture on intracellular concentrations. J. Gen. Physiol. 55:187-207.

11. Gochnauer, M. B., S. C. Kushwaha, M. Kates, and D. Kushner. 1972. Nutritional control of pigment and isoprenoid compound formation in extremely halophilic bacteria. Arch. Microbiol. 84:339-349.

12. Gonzalez, C., C. Gutierrez, and C. Ramirez. 1978. Halobacterium vallismortis $\mathrm{sp}$. nov. An amylolytic and carbohydrate-metabolizing, extremely halophilic bacterium. Can. J. Microbiol. 24:710-715.

13. Holding, A. A., and J. G. Collee. 1971. Routine biochemical tests, p. 1-32. In J. R. Norris and D. W. Ribbons (ed.), Methods in Microbiology, vol. 6A. Academic Press, Inc., London.

14. Houwink, A. L. 1956. Flagella, gas vacuoles and cell-wall structure in Halobacterium halobium: an electron microscope study. J. Gen. Microbiol. 15:146-150.

15. Imhoff, J. F., H. G. Sahl, G. S. H. Soliman, and H. G. Trüper. 1978. The Wadi Natrun: chemical composition and microbial mass development in alkaline brines of eutrophic desert lakes. Geomicrobiol. J. 1:219-234.

16. Kaplan, I. R., and A. Friedman. 1970. Biological productivity in the Dead Sea. I Microorganisms in the water column. Isr. J. Chem. 8:513-528.

17. Lapage, S. P., P. H. A. Sneath, E. F. Lessel, V. B. D. Skerman, H. P. R. Seeliger, and W. A. Clark (ed.). 1975. International code of nomenclature of bacteria. 1975 Revision. American Society for Microbiology, Washington, D.C.

18. Magrum, L. J., K. R. Luehrsen, and C. Woese. 1978. Are extreme halophiles actually "bacteria"? J. Mol. Evol. 11:1-8.

19. Mandel, M., C. L. Schildkraut, and J. Marmur. 1968. Use of $\mathrm{CsCl}$ gradient analysis for determining the guanine plus cytosine content of DNA. Methods Enzymol. 12B:184195.

20. Marmur, J. 1961. A procedure for the isolation of deoxyribonucleic acid from microorganisms. J. Mol. Biol. 3:208218.

21. Mullakhanbhai, M. F., and H. Larsen. 1975. Halobacterium volcanii spec. nov., a Dead Sea halobacterium with a moderate salt requirement. Arch. Microbiol. 104:207-214.

22. Oren, A. 1981. Approaches to the microbial ecology of the Dead Sea. Kiel. Meeresforsch. Sonderh. 5:416-424.

23. Oren, A., and M. Shilo. 1981. Bacteriorhodopsin in a bloom of halobacteria in the Dead Sea. Arch. Microbiol. 130:185-187.

24. Ross, H. N. M., M. D. Collins, B. J. Tindall, and W. D. Grant. 1981. A rapid procedure for the detection of archaebacterial lipids in halophilic bacteria. J. Gen. Microbiol. 123:75-80.

25. Simon, R. D. 1978. Halobacterium strain 5 contains a plasmid which is correlated with the presence of gas vacuoles. Nature (London) 273:314-317.

26. Tindall, B. J., A. A. Mills, and W. D. Grant. 1980. An alkalophilic red halophilic bacterium with a low magnesium requirement from a Kenyan soda lake. J. Gen. Microbiol. 116:257-260.

27. Tomlinson, G. A., and L. I. Hochstein. 1976. Halobacterium saccharovorum sp. nov., a carbohydrate-metabolizing, extremely halophilic bacterium. Can. J. Microbiol. 22:587-591.

28. Tomlinson, G. A., and T. K. Koch. 1974. The metabolism of carbohydrates by extremely halophilic bacteria: glucose metabolism via a modified Entner-Doudoroff pathway. Can. J. Microbiol. 20:1085-1091.

29. Volcani, B. E. 1944. The microorganisms of the Dead Sea, p. 71-81. In Papers collected to commemorate the 70th anniversary of Dr. Chaim Weizmann. Collective volume. Daniel Sieff Research Institute, Rehovoth, Israel.

30. Werber, M. M., and M. Mevarech. 1978. Induction of a dissimulatory reduction pathway of nitrate in Halobacterium of the Dead Sea. Arch. Biochem. Biophys. 186:6065. 